\title{
WPS3532
}

\section{Remittances, Household Expenditure and Investment in Guatemala}

Richard H. Adams, Jr.

Development Research Group (DECRG)

\section{MSN MC3-303 \\ World Bank \\ 1818 H Street, NW \\ Washington, DC 20433 \\ Phone: 202-473-9037}

Email: radams@worldbank.org

Draft: For comments only

World Bank Policy Research Working Paper 3532, March 2005

The Policy Research Working Paper Series disseminates the findings of work in progress to 
encourage the exchange of ideas about development issues. An objective of the series is to get the findings out quickly, even if the presentations are less than fully polished. The papers carry the names of the authors and should be cited accordingly. The findings, interpretations, and conclusions expressed in this paper are entirely those of the authors. They do not necessarily represent the view of the World Bank, its Executive Directors, or the countries they represent. Policy Research Working Papers are available online at http://econ.worldbank.org. 


\begin{abstract}
$\underline{\text { Abstract }}$
This paper uses a large household data set from Guatemala to analyze how the receipt of internal remittances (from Guatemala) and international remittances (from the United States) affects the marginal spending behavior of households on various consumption and investment goods. Contrary to other studies, this study finds that households receiving remittances actually spend less at the margin on consumption food and consumer goods and durables - than do households receiving no remittances. Instead of spending on consumption, households receiving remittances tend to spend more on investment goods, like education, health and housing. The analysis shows that a large amount of remittance money goes into education. At the margin, households receiving internal and international remittances spend 45 and 58 percent more, respectively, on education than do households with no remittances. These increased expenditures on education represent investment in human capital. Like other studies, this paper finds that remittance-receiving households spend more at the margin on housing. These increased expenditures on housing represent a type of investment for the migrant as well as a means for boosting local economic development by creating new income and employment opportunities for skilled and unskilled workers.
\end{abstract}


Remittances refer to the money and goods that are transmitted to households by migrant workers working outside their communities of origin. These resource transfers represent one of the key issues in economic development. In 2004 official international remittances were estimated at $\$ 93$ billion per year (Ratha, 2004), ${ }^{\mathrm{i}}$ making them about twice as large as the level of official aid-related flows to developing countries.

From the standpoint of economic development, the basic question is simple: How are these huge amounts of remittance monies spent or used? Do migrant workers channel their remittance earnings into human and physical capital investments back home, or do they merely use these monies to purchase new "status-oriented" consumer goods for themselves and their families?

In general, researchers and policymakers have tended to take a rather pessimistic view of how remittances are spent or used and the impact of these monies on economic development. For example, a recent review of the literature by Chami, Fullenkamp and Jahjah (2003:10-11) reports three stylized facts: first, that a "significant proportion, and often the majority," of remittances are spent on consumption; second, that a smaller part of remittance funds goes into saving or investment; and third, the ways in which remittances are typically saved or invested - in housing, land and jewelry - are "not necessarily productive" to the economy as a whole.

Several interrelated factors seem to be responsible for this dim view of the impact of remittances on economic development. On a most basic level, since decisions on how to spend remittances are made by thousands (if not millions) of individual households, it is difficult to establish exactly how these monies are used. Much of the literature in this 
area thus tends to be anecdotal, rather than empirical. At the same time, household budget surveys, which represent the best possible source of information about how remittances are spent, are often poorly designed. Oftentimes, these household surveys do not even include questions about remittances. Moreover, the limited number of surveys that do ask questions about remittances typically ask "naïve" questions about these monies were spent or used. Since remittances are fungible like any other source of income, simply asking respondents about how remittances were spent is not enough. Remittances that are not being spent directly on investment may well have freed other resources for expenditures on investment. Third, the small handful of empirically-based studies that do exist on remittances and economic development are often based on small, unrepresentative household samples. For instance, Adams (1991) study of how international remittances are used in rural Egypt is based on only 150 households, while Alderman's (1996) and Adams' (1998) studies in rural Pakistan are based on 500 households. ${ }^{\text {ii }}$ Clearly, there is a need to extend the scope of these studies to examine the impact of remittances on economic development by using larger, nationally representative samples.

The purpose of this paper is to extend the debate concerning how remittances are spent or used and their impact on economic development by using the results of a recent large, nationally-representative household budget survey in Guatemala. The results of this survey are used to compare the marginal spending behavior of three groups of households: those receiving no remittances, those receiving internal remittances (from Guatemala) and those receiving international remittances (from the United States). Since all survey households are separated into one of these three groups, it becomes possible to 
compare the marginal budget shares of remittance- and non-remittance receiving households to various categories of consumption and investment goods. This comparative, and much more nuanced, view of how remittances are spent or used will hopefully enable us to transcend those positions that merely proclaim that remittances are "not productive" to the overall economy.

This paper proceeds in six sections. Section 1 provides an overview of the data set. Section 2 discusses the choice of the functional form for the model, and Section 3 specifies and estimates the model. Section 4 presents the empirical results, which show that households receiving remittances spend less at the margin on food and more at the margin on housing and education than do non-remittance receiving households. Section 5 explores the ramifications of this finding by disaggregating marginal expenditures on housing and education by income quintile group and level of education. Section 6 summarizes the main findings.

\section{Data Set}

Data for the study come from a national household survey done by the Instituto Nacional de Estadistica in Guatemala during the period July to December 2000. ${ }^{\text {iii }}$ The survey included 7,276 urban and rural households and was designed to be statistically representative both at the national level and for urban and rural areas. The survey was comprehensive, collecting detailed information on a wide range of topics, including income, expenditure, education, financial assets, household enterprises and remittances. ${ }^{\text {iv }}$

It should, however, be emphasized that this Guatemala survey was not designed as a migration or remittances survey. In fact, the survey collected very limited 
information on these topics. With respect to migration, the survey collected no information on the characteristics of the migrant: age, education or income earned away from home. On the issue of remittances, the survey only asked three basic questions: (1) Does your household receive remittances from family or friends?; (2) Where do these people sending remittances live?; ${ }^{\mathrm{v}}$ and (3) How much (remittance) money did your household receive in the past 12 months?

The lack of data on migrant characteristics in the Guatemala survey is unfortunate, and makes it virtually impossible to control for possible selectivity bias in the decision to migrate. However, the focus of this paper is on remittances, not migration. Since remittances are fungible like any other source of income, the presence of possible selectivity bias in the decision to migrate should not be such an issue, because the conventional argument is that since "a dollar is a dollar" households will spend their income without regard to the source of that income. In other words, most economists would argue that remittance income - received by either rich or poor households - will be spent just like any other income. One underlying goal of this paper, therefore, is to challenge this conventional way of thinking by showing how the marginal spending patterns of households receiving remittances are qualitatively different from those households which do not receive remittances.

Table 1 presents summary data from the Guatemala survey. This table shows that 5,665 households (77.8 percent of all households) received no remittances, 1,063 households (14.6 percent) received internal remittances (from Guatemala) and 593 households (8.1 percent) received international remittances (from USA). About 88 households received both internal and international remittances and, since there is no way 
to separate how many of these households received internal versus international remittances, these 88 households are counted in both columns of remittance-receivers. A smaller number of households (43) received remittances from other countries (such as Central American or "other"), and are not counted as remittance-receiving households in this study.

The data in Table 1 reveal several interesting contrasts between the three groups of households, that is, those receiving no remittances, those receiving internal remittances (from Guatemala) and those receiving international remittances (from USA). On average, when compared to non-remittance households, households receiving remittances (internal or international) have more education, fewer children under age 5 and are more likely to live in urban areas. In a broad sense these findings tend to accord with human capital theory, which suggests that educated people are more likely to migrate because educated people enjoy greater employment and income opportunities in destination areas.

The Guatemala survey also collected detailed information on a wide variety of household expenditures. As shown in Table 2, data were collected on six major categories of expenditure, and on several subdivisions within each category. While the time base over which these expenditure outlays were measured varied (from last 7 days for most food items, to last year for most durable goods), all expenditures were aggregated to obtain yearly values. For household durables (stove, refrigerator, automobile, etc), annual use values were calculated to obtain an estimate of the cost of one year's use of that good. Annual use values were also calculated to obtain an estimate of the one year use value of housing (rented or owned). 
Table 3 presents average budget shares devoted to the six categories of expenditure for the three groups of households: those receiving no remittances, those receiving internal remittances (from Guatemala) and those receiving international remittances (from USA). On average, each of the three groups of households spends over 55 percent of their budgets on the two categories of goods that are clearly consumption items: food and consumer goods, durables. This is not too remarkable. However, it is interesting to note the differences in average budget shares between the three groups of households. On average, households receiving internal or international remittances spend less on food and more on housing and education than do non-remittance receiving households. This suggests that there may be differences in the marginal spending patterns between remittance-receiving and non-remittance households. This issue will be the focus of our analysis in the next three sections.

\section{Choice of Functional Form}

To analyze the marginal expenditure patterns of remittance-receiving and nonreceiving households, it is necessary to choose a proper functional form for the econometric model. The selected functional form must do several things. First, it must provide a good statistical fit to a wide range of goods, including food, housing and education. Second, because of the focus here on expenditure-consumption relationships, the chosen form must have a slope that is free to change with expenditure. In this study expenditure elasticities as well as marginal propensities to spend need to be calculated. A model specification that imposes the same slope (or marginal budget share) for all levels of expenditure would not be useful. What is needed is a functional form that 
mathematically allows for rising, falling or constant marginal propensities to spend over a broad range of goods and expenditure levels. Third, the chosen form should conform with the criterion of additivity. To be internally consistent the sum of the marginal propensities for all goods should equal unity.

Assume for the moment that all households differ only in the level of their total expenditure. A linear functional form would then be too restrictive for analyzing their marginal expenditure patterns. The linear Engel curve:

$$
\mathrm{C}_{i}=a_{i}+\beta_{i} E X P
$$

where $\mathrm{C}_{i}=$ expenditure on good $\mathrm{i}, \mathrm{EXP}=$ total expenditure and $a=$ constant, does not permit the marginal budget share $\left(\beta_{i}\right)$ to vary at all.

For this reason, a nonlinear function is required for the analysis. In the literature a wide variety of nonlinear functional forms for Engel curves has been explored. For example, in their classic study of Engel curves, Prais and Houthakker (1971) experiment with double logarithmic, semilogarithmic and log reciprocal forms. While each of these functional forms has some claim to superiority for the analysis of certain goods, none of these forms conforms fully with the criterion of additivity. One very useful functional form which is consistent with the criterion of adding up is the Working-Leser model, which relates budget shares linearly to the logarithm of total expenditure. A modified version of the Working-Leser model represents the basic form that will be used in this analysis. ${ }^{\mathrm{vi}}$ It can be written as:

$$
C_{i} / E X P=\beta_{i}+a_{i} / E X P+\gamma_{i}(\log E X P)
$$

where $C_{i} / E X P$ is the share of expenditure on good i in total expenditure EXP. Adding up requires that $\Sigma C_{i} / \mathrm{EXP}=1$. 
Equation (2) is equivalent to the Engel function:

$$
\mathrm{C}_{i}=a_{i}+\beta_{i} E X P+\gamma_{i}(E X P)(\log E X P)
$$

In comparing the expenditure behavior of households with different levels of income, various socioeconomic and locational factors other than expenditure must be taken into account. Part of the observed differences in expenditure behavior may be due, for example, to differences in household composition (family size, number of children, etc), education, urban or rural residence, geographic region or (in this sample) receipt of internal or international remittances. These household characteristic variables thus need to be included in the Engel functions in a way that allows them to shift both the intercept and the slope of the Engel functions. Let $\mathrm{Z}_{\mathrm{j}}$ denote the $\mathrm{jth}$ household characteristic variable and let $\mu_{\mathrm{ij}}$ and $\lambda_{\mathrm{ij}}$ be constants. The complete model is then:

$$
\mathrm{C}_{i}=a_{i}+\beta_{i} E X P+\gamma_{i}(E X P)(\log E X P)+\Sigma_{j}\left[\left(\mu_{\mathrm{ij}}\right)\left(\mathrm{Z}_{\mathrm{j}}\right)+\lambda_{\mathrm{ij}}(\mathrm{EXP})\left(\mathrm{Z}_{\mathrm{j}}\right)\right]
$$

In semi-log ratio form, this is equivalent to:

$$
C_{i} / E X P=\beta_{i}+a_{i} / E X P+\gamma_{i}(\log E X P)+\Sigma_{j}\left[\left(\mu_{\mathrm{ij}}\right) \mathrm{Z}_{\mathrm{j}} / \mathrm{EXP}+\lambda_{\mathrm{ij}}\left(\mathrm{Z}_{\mathrm{j}}\right)\right]
$$

Including the various household characteristic variables in equation (5) is important, because it introduces considerably more flexibility in the way that marginal budget shares can vary by household type.

From equation (5) the marginal and average budget shares for the ith good (the $\mathrm{MBS}_{\mathrm{i}}$ and $\mathrm{ABS} \mathrm{i}_{\mathrm{i}}$, respectively) and the expenditure elasticity $\left(\xi_{i}\right)$ can be derived as follows:

$$
\begin{aligned}
& M B S_{i}=d C_{i} / d E X P=\beta_{i}+\gamma_{i}(1+\log E X P)+\Sigma_{j}\left[\left(\gamma_{i j}\right)\left(Z_{j}\right)\right] \\
& A B S_{i}=C_{i} / E X P_{i} \\
& \xi_{i}=M B S_{i} / A B S_{i}
\end{aligned}
$$


To estimate equation (5), the various household characteristic variables need to be specified and identified. Therefore, let HS be the variable for family size, AGEHD be the variable for age of household head, CHILD5 (number of children below age 5) the variable for number of children, EDPREP is number of household members over age 15 with preparatory education, EDPRIM is number of household members over age 15 with primary education, EDSEC is number of household members over age 15 with secondary education, EDUNIV is number of household members over age 15 with higher (university) education. In addition, since urban or rural residence and geographic region may affect expenditure patterns, let AR ( 1 if urban, 2 if rural) be the variable for urban/rural location and REG (region) represent a set of seven regional dummy variables (with metropolitan region omitted). Also let INTREM be the dummy variable for the receipt of internal remittances and EXTREM be the dummy variable for the receipt of international remittances. The complete model to be estimated is then:

$$
\begin{aligned}
\mathrm{C}_{\mathrm{i}} / \mathrm{EXP} & =\beta_{1}+\alpha_{\mathrm{i}} / \mathrm{EXP}+\gamma_{1}(\log \mathrm{EXP})+\gamma_{2} \text { INTREM }+\gamma_{3}(\text { INTREM })(\log \mathrm{EXP}) \\
& +\gamma_{4} \mathrm{EXTREM}+\gamma_{5}(\mathrm{EXTREM})(\log \mathrm{EXP})+\mu_{1} \mathrm{HS} / \mathrm{EXP}+\lambda_{1} \mathrm{HS} \\
& +\mu_{2} \mathrm{AGEHD} / \mathrm{EXP}+\lambda_{2} \mathrm{AGEHD}+\mu_{3} \mathrm{CHILD} 5 / \mathrm{EXP} \\
& +\lambda_{3} \mathrm{CHILD} 5+\mu_{4} \mathrm{EDPREP} / \mathrm{EXP}+\lambda_{4} \mathrm{EDPREP}+\mu_{5} \mathrm{EDPRIM} / \mathrm{EXP} \\
& +\lambda_{5} \mathrm{EDPRIM}+\mu_{6} \mathrm{EDSEC} / \mathrm{EXP}+\lambda_{6} \mathrm{EDSEC}+\mu_{7} \mathrm{EDUNIV} / \mathrm{EXP} \\
& +\lambda_{7} \mathrm{EDUNIV}+\delta_{1} \mathrm{AR}+\delta_{2} \sum_{j=1}^{7} \lambda_{j} R E G_{\mathrm{j}}+
\end{aligned}
$$


where:

$\mathrm{C}_{\mathrm{i}}=$ annual per capita household expenditure on one of six expenditure categories defined above (food, consumer goods/durables, housing, education, health or other)

$\mathrm{EXP}=$ total annual per capita household expenditure

INTREM = internal remittances dummy variable $(1$ if household receives internal remittances, 0 otherwise)

EXTREM = international remittances dummy variable (1 if household receives international remittances, 0 otherwise)

In equation (9) the dummy variables for the receipt of internal and international remittances (INTREM and EXTREM) are entered separately and linearly, and each of these dummy variables is also interacted with the log of total annual expenditures (log EXP) in order to affect both the intercept and the slope of the Engel functions. This means that the marginal budget share for the ith good $\left(\mathrm{MBS}_{\mathrm{i}}\right)$ can be derived as follows:

$$
\begin{aligned}
& (\text { when INTREM, EXTREM }=0) \mathrm{MBS}_{i}=\text { equation }(6) \\
& \begin{aligned}
(\text { when INTREM = }) \mathrm{MBS}_{i} & =\beta_{i}+\gamma_{2}+\left(\gamma_{1}+\gamma_{3}\right)[(1+(\text { INTREM })(\log \text { EXP })] \\
& +\Sigma_{j}\left[\left(\gamma_{i j}\right)\left(Z_{j}\right)\right]
\end{aligned} \\
& \begin{aligned}
\left(\text { when EXTREM = 1) } \mathrm{MBS}_{i}\right. & =\beta_{i}+\gamma_{4}+\left(\gamma_{1}+\gamma_{5}\right)[(1+(\text { EXTREM })(\log \text { EXP })] \\
& +\Sigma_{j}\left[\left(\gamma_{i j}\right)\left(Z_{j}\right)\right]
\end{aligned}
\end{aligned}
$$

\section{Estimation of the Model}

Equation (9) was estimated on all 7,276 households in the survey. The equation was estimated in two ways: first, with no dummy variables for the receipt of internal or 
international remittances; and second, including both remittance variables. In both estimations the model was estimated for each of the 6 categories of expenditures: food, consumer goods/durables, housing, education, health and other. The basic estimation technique was ordinary least squares (OLS).

Results are shown in Tables 4 and 5. Table 4 shows the results without remittance variables, and Table 5 shows the results with both remittance variables.

Since the focus here is on understanding how remittances affect household expenditure, we will concentrate on the results in Table 5 for the interactive term: internal (or international) remittances times log of total annual per capita household expenditures. In Table 5 the interactive term for both remittance variables $($ INTREM $)(\log$ EXP) and $($ EXTREM $)(\log$ EXP $)$ - is statistically significant in 4 of 12 cases. With respect to internal remittances, when the relevant coefficients $[(\operatorname{logEXP})$ and $($ INTREM $)(\log E X P)]$ are summed up to arrive at the full expenditure relationship, the results show that households receiving internal remittances spend less on food, and more on consumer goods/durables, housing, health and other. These latter findings are encouraging because while food represents a consumption good, health is more like an investment item. With respect to international remittances, when the relevant coefficients $[(\operatorname{logEXP})$ and $(\mathrm{EXTREM})(\operatorname{logEXP})]$ are added up, the results are identical to those for internal remittances.

\section{Empirical Results: Remittances and Household Expenditure Behavior}

The purpose of this paper is to compare the expenditure behavior of three groups of households: those receiving no remittances, those receiving internal remittances and 
those receiving international remittances. To do this, the results of equation (9) can be used to calculate marginal budget shares for the three groups of households for each of the six categories of expenditure. This makes it possible to identify at the margin how the receipt of internal or international remittances affects the expenditure patterns of households in Guatemala.

Table 6 presents the marginal budget shares for the households on the various categories of expenditure. Three results are noteworthy. First, households receiving remittances spend less at the margin on food than non-remittance receiving households. At the margin, households receiving internal and international remittances spend 11.9 and 14.8 percent less, respectively, on food than do non-remittance receiving households. There is no evidence here that remittance-receiving households "waste" their increased earnings on "conspicuous" food consumption. Second, households receiving remittances spend more of their increments to expenditure on housing than do non-remittance receiving households. The percentage increases for marginal spending on housing are 15.3 percent for households receiving internal remittances and 2.2 percent for households receiving international remittances. Like other studies, ${ }^{\text {vii }}$ this suggests that remittancereceiving households are devoting much of their increments to expenditure on housing. From the standpoint of the economy as a whole, these expenditures on housing represent consumption expenditure. However, from the standpoint of the individual migrant, these expenditures on housing represent investment to the extent that they provide some expected future rate of financial return. Third, while the absolute levels of expenditure are quite small, remittance-receiving households are spending considerably more at the margin on education. The percentage increases for marginal spending on education, 
which are the largest in the table, are 45.2 percent for households receiving internal remittances and 58.1 percent for households receiving international remittances. These large marginal increases in spending on education are important because increased expenditure on education can raise the level of human capital in the country as a whole. Since the level of human capital is an important component of economic growth, increased expenditure on education by remittance-receiving households may provide the means for raising the rate of economic growth in a country.

\section{Remittances and Household Expenditure on Housing and Education}

Two of the more striking findings from the previous section are that households receiving remittances spend more at the margin on housing and education than do households which do not receive remittances. Since households receiving remittances also enjoy higher levels of per capita income (expenditure), ${ }^{\text {viii }}$ it is possible that these findings are driven by the higher levels of income (expenditure) enjoyed by remittancereceiving households. For this reason, it is important to compare the expenditure behavior of non-remittance and remittance-receiving households on housing and education, when controlling for the level of total expenditure.

This can be done by ranking all 7,276 households in the data set into quintile groups on the basis of total annual per capita expenditure, including remittances. The 7,276 households can then be divided into three groups: those receiving no remittances, those receiving internal remittances and those receiving international remittances. The regression results reported above can then be used to calculate expenditure elasticities and marginal budget shares for the various quintile groups. This makes it possible to 
compare the marginal budget shares to housing and education at similar levels of expenditure for the three groups of households.

Tables 7 and 8 show the expenditure behavior on housing and education for the three groups of households. Within each group of households, quintile means are determined by aggregating mean individual household values, and all households are evaluated on the basis of per capita income including remittances. Thus, the main difference for any quintile group between the three groups of households is that the "no remittance" group received no remittances, while the other two groups received either internal or international remittances.

Table 7 presents the expenditure behavior for housing (annual use value of housing). At the mean, marginal budget shares to housing are low - less than 0.22 - for each of the three groups of households. However, for 9 of the 10 quintile groups, marginal budget shares to housing are higher for remittance-receiving households as opposed to non-remittance receiving households. This means that at most levels of expenditure, households receiving remittances are spending more of their increments to expenditure on housing. This is a key finding because it suggests that when controlling for level of expenditures, the marginal spending patterns of remittance-receiving households are qualitatively different from households not receiving remittances. Moreover, remittance-inspired expenditures on housing are productive for the economy as a whole, since they have important second- and third-round effects on wages, employment and business opportunities. As households receiving remittances spend more at the margin on housing, this creates new income and employment opportunities for skilled and unskilled laborers, and new business opportunities for merchants selling 
brick, wood and other building materials. As a result, the increased level of spending on housing provided by remittances could provide an important stimulus for local economic development "from the bottom up.,"ix

Table 8 presents the expenditure behavior for education (educational expenses) for the three groups of households. At the mean, marginal budget shares to education are even lower than those for housing: 0.050 or less for each of the three groups of households. However, for 7 of the 10 quintile groups, marginal budget shares to education are higher for remittance-receiving households as opposed to non-remittance receiving households. In other words, when controlling for level of expenditures, households receiving remittances tend to spend more of their additional increments to expenditure on education.

Since these patterns of increased investment in human capital may have important ramifications for the economy as a whole, it is useful to disaggregate the nature of these remittance-inspired expenditures on education. Specifically, it is interesting to examine how remittance-receiving households allocate funds at the margin to different levels of education. For example, are remittance-receiving households allocating more of their extra increments to expenditure on primary, secondary or university education?

It is possible to address these questions by estimating a slightly revised version of the original regression (equation (9)): 


$$
\begin{aligned}
\mathrm{ED}_{i} / \mathrm{EXP} & =\beta_{1}+\alpha_{\mathrm{i}} / \mathrm{EXP}+\gamma_{1}(\log \mathrm{EXP})+\gamma_{2} \mathrm{INTREM}+\gamma_{3}(\mathrm{INTREM})(\log \mathrm{EXP}) \\
& +\gamma_{4} \mathrm{EXTREM}+\gamma_{5}(\mathrm{EXTREM})(\log \mathrm{EXP})+\mu_{1} \mathrm{HS} / \mathrm{EXP}+\lambda_{1} \mathrm{HS} \\
& +\mu_{2} \mathrm{AGEHD} / \mathrm{EXP}+\lambda_{2} \mathrm{AGEHD}+\mu_{3} \mathrm{CHILD} 5 / \mathrm{EXP}+\lambda_{3} \mathrm{CHILD} 5 \\
& +\mu_{4} \mathrm{EDHD} / \mathrm{EXP}+\lambda_{4} \mathrm{EDHD}+\mu_{5} \mathrm{FEMHD} / \mathrm{EXP}+\lambda_{5} \mathrm{FEMHD}+\delta_{1} \mathrm{AR} \\
& +\delta_{2} \sum_{j=1}^{7} \lambda_{j} R E G_{\mathrm{j}}+
\end{aligned}
$$

where:

$$
\begin{aligned}
& \mathrm{ED}_{i}=\text { annual per capita household expenditure on one of four levels of } \\
& \quad \text { education (preparatory, primary, secondary or higher/university) } \\
& \mathrm{EDHD}=\text { years of education of household head } \\
& \text { FEMHD = female head of household dummy ( } 1 \text { if household head is female, } 0 \\
& \text { otherwise) and all other variables are defined as in equation (9) }
\end{aligned}
$$

Equation (13) can be estimated separately for each of the 3 groups of households: those receiving no remittances, those receiving internal remittances and those receiving international remittances. It can also estimated separately for each of the 4 levels of education: preparatory (1-2 years), primary (grades 1-6), secondary (grades 7-12) and higher/university (4 years).

Parameter results from equation (13) are shown in Tables 9 and 10. Table 9 shows the results without remittance variables, and Table 10 shows the results with both remittance variables.

Since the goal is to understand how remittances affect marginal expenditures on different levels of education, the focus here is on the interactive term: log of total annual per capita household expenditures times remittances dummy. In Table 10 the interactive 
term for internal remittances [(INTREM)(log EXP)] is statistically significant for only the highest level of education: higher/university education. In the same table the interactive term for international remittances [(EXTREM)(log EXP] is positive and significant for secondary education.

The results from equation (13) can be used to calculate marginal budget shares for the three groups of households for each level of education. These marginal budget shares are shown in Table 11. When compared to non-remittance receiving households, households receiving internal and international remittances allocate slightly more of their increments to education on the lower levels of education: preparatory and primary school. However, at the higher levels of education - and especially at the secondary school level - households receiving remittances allocate considerably more of their increments to expenditure on education. At the margin, households receiving internal and international remittances spend 19.6 and 142.4 percent more, respectively, on secondary school education than do non-remittance receiving households. Households receiving international remittances also spend more at the margin on higher/university education than do non-remittance receiving households. ${ }^{\mathrm{x}}$

The results from Table 11 suggest that remittance-receiving households in Guatemala are spending their increments to expenditure with an eye to the expected differential rates of return to various levels of education. For example, a recent World Bank study on Guatemala (2004: Table 7:3) found that when compared to those with no education, people who had completed primary education received 15 percent more in hourly wages, while those who had completed secondary or university education received 51 or 74 percent more, respectively. Households in Guatemala receiving internal or 
international remittances are evidently allocating their increments to expenditure to try to take advantage of these higher rates of return to secondary and university education.

\section{Conclusion}

This paper has used a large, nationally representative household survey from Guatemala to analyze how the receipt of internal remittances (from Guatemala) and international remittances (from the United States) affects the marginal spending behavior of households on various consumption and investment goods. Three key findings emerge.

First, contrary to other studies, this analysis finds that the majority of remittance earnings are not spent on consumption goods. In fact, at the mean level of expenditure, this study finds that while households without remittances spend 58.9 percent of their increments to expenditure on consumption goods - food and consumer goods, durables households receiving internal and international remittances spend 54.2 and 55.9 percent, respectively, on consumption goods. ${ }^{\mathrm{xi}}$ In other words, at the margin, households receiving remittances actually spend less - not more - on consumption than do households without remittances. There is no evidence here that households receiving remittances tend to "waste" their remittance earnings on "conspicuous" consumption.

The second finding follows closely from the first. This study finds that the marginal spending behavior of households receiving remittances is qualitatively different from that of households which do not receive remittances. Instead of spending more on consumption, households receiving remittances tend to view their remittance earnings as a temporary (and possibly uncertain) stream of income, one to be spent more on 
investment than consumption goods. For example, while the absolute levels of expenditure are small, households receiving remittances in this study spend considerably more on education. At the margin, households receiving internal and international remittances spend 45.2 and 58.1 percent more, respectively, on education than households which do not receive remittances. When disaggregated by level of education, most of these increments to expenditure on education go into higher education, especially at the secondary school level. Not only does this increased marginal spending on education underscore the way that households prefer to invest - rather than to spend their remittance earnings, but it also shows how remittance expenditures can be productive for the economy as a whole. Increased expenditure on secondary school education by remittance-receiving households can help raise the level of human capital in the country as whole, thereby boosting the rate of overall economic growth.

Third, this analysis confirms other studies' findings concerning the amount of remittance money that goes into housing. At the margin, households receiving internal and international remittances are spending 15.3 and 2.2 percent more, respectively, on housing than those households which do not receive remittance. From the standpoint of the economy as a whole, these increased expenditures on housing represent consumption expenditure. However, from the standpoint of the individual migrant, these increased expenditures on housing represent investment when they provide some expected future rate of financial return. Moreover, increased expenditures on housing are productive for the economy as a whole because they have important second- and third-round effects on wages, employment and business opportunities. As households receiving remittances spend more at the margin on housing, this creates new income and employment 
opportunities for laborers, and new business opportunities for merchants selling building supplies. In the future, more work needs to be done on measuring the multiple-round effects of these remittance-inspired increases in housing expenditure on the economy at large. 


\section{$\underline{\text { References }}$}

Adams, Jr., Richard. 1991. The Effects of International Remittances on Poverty, Inequality and Development in Rural Egypt. Research Report 86. International Food Policy Research Institute, Washington, DC.

Adams, Jr., Richard. 1998. "Remittances, Investment and Rural Asset Accumulation in Pakistan.'Economic Development and Cultural Change, 47, 155-173.

Alderman, Harold. 1996. "Saving and Economic Shocks in Rural Pakistan." Journal of Development Economics, 51, 343-365.

Chami, Ralph, Connel Fullenkamp and Samir Jahjah. 2003. "Are Immigrant Remittance Flows a Source of Capital for Development?" International Monetary Fund (IMF) Working Paper 03/189. Washington, DC.

Edwards, Alejandra and Manuelita Ureta. 2003. "International Migration, Remittances and Schooling: Evidence from El Salvador.” Journal of Development Economics, 72, 429-461.

Gilani, Ijaz, M. Khan and Munawar Iqbal. 1981. Labor Migration from Pakistan to the Middle East and Its Impact on the Domestic Economy. Research Report 127. Pakistan Institute of Development Economics, Islamabad, Pakistan.

Osili, Una. 2004. "Migrants and Housing Investments: Theory and Evidence from Nigeria." Economic Development and Cultural Change, 52, 821-849.

Prais, S. J. and H. S. Houthakker. 1971. The Analysis of Family Budgets. Cambridge: Cambridge University Press.

Ratha, Dilip. 2004. "Enhancing the Developmental Effect of Workers' Remittances to Developing Countries.” In World Bank, Global Development Finance, pp. 169173. Washington, DC.

Taylor, J. Edward and Irma Adelman. 1996. Village Economies: The Design, Estimation and Use of Villagewide Models. Cambridge: Cambridge University Press.

World Bank. 2004. Poverty in Guatemala. Washington, DC. 
Table 1. Summary Data on Non-Remittance and Remittance-Receiving Households, Guatemala, 2000

\begin{tabular}{|c|c|c|c|c|c|}
\hline Variable & $\begin{array}{l}\text { Receive no } \\
\text { remittances }\end{array}$ & $\begin{array}{c}\text { Receive } \\
\text { internal } \\
\text { remittances } \\
\quad \text { (from } \\
\text { Guatemala) } \\
\end{array}$ & $\begin{array}{c}\text { Receive } \\
\text { international } \\
\text { remittances } \\
\text { (from USA) }\end{array}$ & $\begin{array}{c}\text { t-test }(\mathrm{No} \\
\text { remittances vs. } \\
\text { internal } \\
\text { remittances) }\end{array}$ & $\begin{array}{c}\text { t-test }(\mathrm{No} \\
\text { remittances vs. } \\
\text { international } \\
\text { remittances }\end{array}$ \\
\hline $\begin{array}{l}\text { Mean } \\
\text { household size }\end{array}$ & $\begin{array}{c}5.32 \\
(2.46)\end{array}$ & $\begin{array}{c}4.74 \\
(2.69)\end{array}$ & $\begin{array}{c}5.18 \\
(2.68)\end{array}$ & $6.50 * *$ & 0.52 \\
\hline $\begin{array}{l}\text { Mean age of } \\
\text { household } \\
\text { head (years) }\end{array}$ & $\begin{array}{c}42.75 \\
(14.24)\end{array}$ & $\begin{array}{c}50.96 \\
(16.66)\end{array}$ & $\begin{array}{c}48.34 \\
(16.12)\end{array}$ & $-17.03 * *$ & $-9.32 * *$ \\
\hline $\begin{array}{l}\text { Mean number } \\
\text { of males in } \\
\text { household over } \\
\text { age } 15\end{array}$ & $\begin{array}{l}1.35 \\
(0.84)\end{array}$ & $\begin{array}{l}1.19 \\
(0.98)\end{array}$ & $\begin{array}{c}1.21 \\
(1.00)\end{array}$ & $6.67 * *$ & $3.52 * *$ \\
\hline $\begin{array}{l}\text { Mean number } \\
\text { of children in } \\
\text { household } \\
\text { under age } 5\end{array}$ & $\begin{array}{c}0.88 \\
(0.96)\end{array}$ & $\begin{array}{c}0.62 \\
(0.89)\end{array}$ & $\begin{array}{c}0.69 \\
(0.96)\end{array}$ & $8.14 * *$ & $5.49 * *$ \\
\hline $\begin{array}{l}\text { Mean number } \\
\text { of household } \\
\text { members over } \\
\text { age } 15 \text { with } \\
\text { secondary } \\
\text { education }\end{array}$ & $\begin{array}{c}0.94 \\
(1.07)\end{array}$ & $\begin{array}{l}1.01 \\
(1.19)\end{array}$ & $\begin{array}{l}1.09 \\
(1.17)\end{array}$ & $-2.07 *$ & $-4.17 * *$ \\
\hline $\begin{array}{l}\text { Area }(1= \\
\text { urban, } 2= \\
\text { rural })\end{array}$ & $\begin{array}{c}1.58 \\
(0.49)\end{array}$ & $\begin{array}{l}1.49 \\
(0.50)\end{array}$ & $\begin{array}{l}1.52 \\
(0.49)\end{array}$ & $6.51 * *$ & $5.02 * *$ \\
\hline $\begin{array}{l}\text { Mean annual } \\
\text { per capita } \\
\text { income } \\
\text { (excluding } \\
\text { remittances) in } \\
\text { Guatemalan } \\
\text { quetzals }\end{array}$ & $\begin{array}{r}6,798.98 \\
(14,021.5)\end{array}$ & $\begin{array}{r}6,523.24 \\
(8,351.7)\end{array}$ & $\begin{array}{r}7,042.01 \\
(13,307.4)\end{array}$ & 0.45 & -0.12 \\
\hline $\mathrm{N}$ & 5,665 & 1,063 & 593 & & \\
\hline
\end{tabular}

Notes: $\quad \mathrm{N}=7,276$ households; 88 households receive both internal remittances (from Guatemala) and international remittances (from USA). All values are weighted; standard deviations are in parentheses.

In 2000, 1 Guatemalan quetzal $=$ US\$0.128.

Source: Guatemala 2000 ENCOVI Survey, Instituto Nacional de Estadistica.

*Significant at the 0.05 level. **Significant at the 0.01 level. 
Table 2. Expenditure Categories in Guatemala Household Survey, 2000

\begin{tabular}{|c|c|c|}
\hline Category & Description & Examples \\
\hline Food & $\begin{array}{l}\text { Purchased food } \\
\text { Non-purchased food }\end{array}$ & $\begin{array}{l}\text { Bread, tortillas, milk, meat, } \\
\text { fruit, vegetables } \\
\text { Food from: own- } \\
\text { production, gifts, donations, } \\
\text { social programs }\end{array}$ \\
\hline Consumer goods, durables & $\begin{array}{l}\text { Consumer goods } \\
\text { Household durables }\end{array}$ & $\begin{array}{l}\text { Clothing, shoes, fabric } \\
\text { Annual use value of stove, } \\
\text { refrigerator, furniture, } \\
\text { television, car }\end{array}$ \\
\hline Housing & Housing value & $\begin{array}{l}\text { Annual use value of } \\
\text { housing (calculated from } \\
\text { rental payments or imputed } \\
\text { values) }\end{array}$ \\
\hline Education & Educational expenses & $\begin{array}{l}\text { Books, school supplies, } \\
\text { uniforms, registration fees, } \\
\text { travel to school }\end{array}$ \\
\hline Health & Health expenses & $\begin{array}{l}\text { Doctor fees, medicine, } \mathrm{x}- \\
\text { rays, tests, hospitalization, } \\
\text { health insurance premiums }\end{array}$ \\
\hline Other & $\begin{array}{l}\text { Household services } \\
\text { Transport, communications } \\
\text { Legal, personal services }\end{array}$ & $\begin{array}{l}\text { Water, gas, electricity, } \\
\text { telephone } \\
\text { Bus and taxi fees, gasoline, } \\
\text { faxes, postage, internet } \\
\text { charges } \\
\text { Fees for lawyers, } \\
\text { accountants, professionals }\end{array}$ \\
\hline
\end{tabular}

Source: Guatemala 2000 ENCOVI Survey, Instituto Nacional de Estatistica 
Table 3. Average Budget Shares on Expenditure for Non-Remittance and Remittance-Receiving Households, Guatemala, 2000

\begin{tabular}{|l|l|l|l|}
\hline $\begin{array}{l}\text { Expenditure } \\
\text { Category }\end{array}$ & $\begin{array}{l}\text { Households } \\
\text { receiving no } \\
\text { remittances } \\
\mathbf{( N = 5 6 6 5 )}\end{array}$ & $\begin{array}{l}\text { Households } \\
\text { receiving internal } \\
\text { remittances (from } \\
\text { Guatemala) } \\
\mathbf{( N = 1 0 6 3 )}\end{array}$ & $\begin{array}{l}\text { Households } \\
\text { receiving } \\
\text { international } \\
\text { remittances (from } \\
\text { USA) } \\
\text { (N=593) }\end{array}$ \\
\hline Food & 0.390 & 0.374 & 0.379 \\
\hline $\begin{array}{l}\text { Consumer goods, } \\
\text { durables }\end{array}$ & 0.193 & 0.177 & 0.196 \\
\hline Housing & 0.152 & 0.192 & 0.167 \\
\hline Education & 0.042 & 0.047 & 0.048 \\
\hline Health & 0.039 & 0.040 & 0.034 \\
\hline Other & 0.184 & 0.170 & 0.176 \\
\hline & 1.000 & 1.000 & 1.000 \\
\hline
\end{tabular}

Note: All expenditure categories defined in Table 2.

Source: Guatemala 2000 ENCOVI Survey, Instituto Nacional de Estadistica. 
Table 4. OLS Regression Analysis of Household Expenditure in Guatemala, Without Remittance Variables

\begin{tabular}{|c|c|c|c|c|c|c|}
\hline Variable & Food & $\begin{array}{l}\text { Consumer } \\
\text { goods, } \\
\text { Durables }\end{array}$ & Housing & Education & Health & Other \\
\hline $\begin{array}{l}\text { Reciprocal of total per capita } \\
\text { expenditure }\left(\alpha_{\mathrm{i}} / \mathrm{EXP}\right)\end{array}$ & $\begin{array}{l}-371.096 \\
(-9.81)^{* *}\end{array}$ & $\begin{array}{l}1.243 \\
(-0.05)\end{array}$ & $\begin{array}{l}149.316 \\
(5.75)^{* *}\end{array}$ & $\begin{array}{l}-25.314 \\
(-1.67)\end{array}$ & $\begin{array}{l}47.858 \\
(3.89) * *\end{array}$ & $\begin{array}{l}200.479 \\
(8.05)^{* *}\end{array}$ \\
\hline $\begin{array}{l}\text { Log total annual per capita } \\
\text { household expenditure (log EXP) }\end{array}$ & $\begin{array}{l}-0.115 \\
(- \\
20.24)^{* *}\end{array}$ & $\begin{array}{l}0.048 \\
(12.68)^{* *}\end{array}$ & $\begin{array}{l}0.011 \\
(2.92)^{* *}\end{array}$ & $\begin{array}{l}-0.001 \\
(-0.08)\end{array}$ & $\begin{array}{l}0.015 \\
(8.59)^{* *}\end{array}$ & $\begin{array}{l}0.039 \\
(10.52)^{* *}\end{array}$ \\
\hline Household size (HS) & $\begin{array}{l}0.001 \\
(0.07)\end{array}$ & $\begin{array}{l}0.007 \\
(7.19)^{* *}\end{array}$ & $\begin{array}{l}-0.015 \\
(- \\
14.86)^{* *}\end{array}$ & $\begin{array}{l}0.011 \\
(19.79)^{* *}\end{array}$ & $\begin{array}{l}-0.001 \\
(- \\
2.14) * *\end{array}$ & $\begin{array}{l}-0.003 \\
(-2.97) * *\end{array}$ \\
\hline Household size/total expenditure & $\begin{array}{l}16.284 \\
(4.37)^{* *}\end{array}$ & $\begin{array}{l}-3.864 \\
(-1.54) \\
\end{array}$ & $\begin{array}{l}10.546 \\
(4.12)^{* *}\end{array}$ & $\begin{array}{l}-14.709 \\
(-9.82) * *\end{array}$ & $\begin{array}{l}0.036 \\
(0.03)\end{array}$ & $\begin{array}{l}-8.293 \\
(-3.38)^{* *}\end{array}$ \\
\hline Age of household head (AGEHD) & $\begin{array}{l}-0.001 \\
(-1.21)\end{array}$ & $\begin{array}{l}-0.001 \\
(-13.39)^{* *}\end{array}$ & $\begin{array}{l}0.002 \\
(15.58)^{* *}\end{array}$ & $\begin{array}{l}-0.001 \\
(-7.86) * *\end{array}$ & $\begin{array}{l}0.001 \\
(3.50)^{* *}\end{array}$ & $\begin{array}{l}0.001 \\
(2.35)^{*}\end{array}$ \\
\hline $\begin{array}{l}\text { Age household head/total } \\
\text { expenditure }\end{array}$ & $\begin{array}{l}0.577 \\
(1.14)\end{array}$ & $\begin{array}{l}2.054 \\
(6.03) * * \\
\end{array}$ & $\begin{array}{l}-3.036 \\
(-8.74)^{* *}\end{array}$ & $\begin{array}{l}0.621 \\
(3.06)^{* *}\end{array}$ & $\begin{array}{l}-0.046 \\
(-0.28) \\
\end{array}$ & $\begin{array}{l}-0.171 \\
(-0.51) \\
\end{array}$ \\
\hline $\begin{array}{l}\text { Number of children in household } \\
\text { less than } 5 \text { years (CHILD5) }\end{array}$ & $\begin{array}{l}-0.001 \\
(-0.10)\end{array}$ & $\begin{array}{l}0.005 \\
(2.26)^{*}\end{array}$ & $\begin{array}{l}0.010 \\
(4.41)^{* *}\end{array}$ & $\begin{array}{l}-0.029 \\
(-21.81)^{* *}\end{array}$ & $\begin{array}{l}0.009 \\
(8.01)^{* *}\end{array}$ & $\begin{array}{l}0.006 \\
(2.59)^{* *}\end{array}$ \\
\hline Number children/total expenditure & $\begin{array}{l}1.227 \\
(0.13)\end{array}$ & $\begin{array}{l}-11.980 \\
(-1.94)\end{array}$ & $\begin{array}{l}-12.103 \\
(-1.92)\end{array}$ & $\begin{array}{l}45.895 \\
(12.46)^{* *}\end{array}$ & $\begin{array}{l}-14.000 \\
(- \\
4.70) * *\end{array}$ & $\begin{array}{l}-9.033 \\
(-1.50)\end{array}$ \\
\hline $\begin{array}{l}\text { Number household members } \\
\text { with preparatory education } \\
\text { (EDPREP) }\end{array}$ & $\begin{array}{l}-0.017 \\
(-1.33)\end{array}$ & $\begin{array}{l}0.011 \\
(1.35)\end{array}$ & $\begin{array}{l}0.001 \\
(0.02)\end{array}$ & $\begin{array}{l}-0.003 \\
(-0.67)\end{array}$ & $\begin{array}{l}0.006 \\
(1.40)\end{array}$ & $\begin{array}{l}0.002 \\
(0.33)\end{array}$ \\
\hline $\begin{array}{l}\text { Number preparatory education/total } \\
\text { expenditure }\end{array}$ & $\begin{array}{l}24.187 \\
(0.68)\end{array}$ & $\begin{array}{l}-33.506 \\
(-1.40)\end{array}$ & $\begin{array}{l}23.405 \\
(0.96)\end{array}$ & $\begin{array}{l}-0.102 \\
(-0.01)\end{array}$ & $\begin{array}{l}-9.805 \\
(-0.85)\end{array}$ & $\begin{array}{l}-4.178 \\
(-0.18)\end{array}$ \\
\hline $\begin{array}{l}\text { Number household members } \\
\text { with primary education (EDPRIM) }\end{array}$ & $\begin{array}{l}-0.006 \\
(-2.47)^{*}\end{array}$ & $\begin{array}{l}0.008 \\
(4.80)^{* *}\end{array}$ & $\begin{array}{l}-0.001 \\
(-0.42)\end{array}$ & $\begin{array}{l}-0.005 \\
(-5.24)^{* *}\end{array}$ & $\begin{array}{l}0.002 \\
(2.55)^{*}\end{array}$ & $\begin{array}{l}0.002 \\
(1.21)\end{array}$ \\
\hline $\begin{array}{l}\text { Number primary education/total } \\
\text { expenditure }\end{array}$ & $\begin{array}{l}-7.521 \\
(-1.14) \\
\end{array}$ & $\begin{array}{l}-11.422 \\
(-2.56)^{*} \\
\end{array}$ & $\begin{array}{l}9.216 \\
(2.03)^{*}\end{array}$ & $\begin{array}{l}7.809 \\
(2.94)^{* *}\end{array}$ & $\begin{array}{l}0.566 \\
(-0.26) \\
\end{array}$ & $\begin{array}{l}2.483 \\
(0.57) \\
\end{array}$ \\
\hline $\begin{array}{l}\text { Number household members } \\
\text { with secondary education (EDSEC) }\end{array}$ & $\begin{array}{l}-0.024 \\
(-8.13)^{* *}\end{array}$ & $\begin{array}{l}0.008 \\
(3.82) * *\end{array}$ & $\begin{array}{l}0.001 \\
(0.16)\end{array}$ & $\begin{array}{l}0.011 \\
(9.40)^{* * *}\end{array}$ & $\begin{array}{l}0.004 \\
(3.99)^{* *}\end{array}$ & $\begin{array}{l}0.001 \\
(0.56)\end{array}$ \\
\hline $\begin{array}{l}\text { Number secondary education/total } \\
\text { expenditure }\end{array}$ & $\begin{array}{l}-46.460 \\
(-3.25)^{* *}\end{array}$ & $\begin{array}{l}-15.262 \\
(-1.59)\end{array}$ & $\begin{array}{l}18.477 \\
(1.88)\end{array}$ & $\begin{array}{l}35.409 \\
(6.17) * *\end{array}$ & $\begin{array}{l}-3.672 \\
(-0.79)\end{array}$ & $\begin{array}{l}11.507 \\
(1.22)\end{array}$ \\
\hline $\begin{array}{l}\text { Number household members } \\
\text { with university education } \\
\text { (EDUNIV) }\end{array}$ & $\begin{array}{l}-0.035 \\
(-6.74)^{* *}\end{array}$ & $\begin{array}{l}0.007 \\
(2.02)^{*}\end{array}$ & $\begin{array}{l}-0.001 \\
(-0.41)\end{array}$ & $\begin{array}{l}0.017 \\
(8.36)^{* *}\end{array}$ & $\begin{array}{l}0.006 \\
(3.65)^{* *}\end{array}$ & $\begin{array}{l}0.006 \\
(1.69)\end{array}$ \\
\hline $\begin{array}{l}\text { Number university education/total } \\
\text { expenditure }\end{array}$ & $\begin{array}{l}-33.853 \\
(-0.77) \\
\end{array}$ & $\begin{array}{l}-39.506 \\
(-1.33) \\
\end{array}$ & $\begin{array}{l}52.189 \\
(1.73)\end{array}$ & $\begin{array}{l}-7.388 \\
(-0.42)\end{array}$ & $\begin{array}{l}0.109 \\
(0.01)\end{array}$ & $\begin{array}{l}28.448 \\
(0.98)\end{array}$ \\
\hline Constant & $\begin{array}{l}1.474 \\
(25.48) * *\end{array}$ & $\begin{array}{l}-0.262 \\
(-6.72) * *\end{array}$ & $\begin{array}{l}0.079 \\
(1.99)^{*}\end{array}$ & $\begin{array}{l}0.039 \\
(0.90)\end{array}$ & $\begin{array}{l}-0.128 \\
(- \\
6.82) * *\end{array}$ & $\begin{array}{l}-0.202 \\
(-5.32)^{* *}\end{array}$ \\
\hline Adj. $R^{2}$ & 0.411 & 0.154 & 0.200 & 0.328 & 0.087 & 0.080 \\
\hline F-statistic & 212.5 & 56.4 & 76.8 & 149.3 & 31.6 & 27.4 \\
\hline
\end{tabular}

Notes: $N=7,276$ households. Numbers in parentheses are t-statistics (two-tailed). One area dummy variable and seven regional variables are included in the equation, but are not reported in the table. All expenditure categories defined in Table 2.

*Significant at the 0.05 level. $\quad * *$ Significant at the 0.01 level. 
Table 5. OLS Regression Analysis of Household Expenditure in Guatemala, With Remittance Variables

\begin{tabular}{|c|c|c|c|c|c|c|}
\hline Variable & Food & $\begin{array}{c}\text { Consumer } \\
\text { goods, } \\
\text { Durables } \\
\end{array}$ & Housing & Education & Health & Other \\
\hline $\begin{array}{l}\text { Reciprocal of total per capita } \\
\text { expenditure }\left(\alpha_{\mathrm{i}} / \mathrm{EXP}\right)\end{array}$ & $\begin{array}{l}-375.350 \\
(-9.87)^{* *}\end{array}$ & $\begin{array}{l}-1.961 \\
(-0.08)\end{array}$ & $\begin{array}{l}146.228 \\
(5.60)^{* *}\end{array}$ & $\begin{array}{l}-27.216 \\
(-1.78)\end{array}$ & $\begin{array}{l}47.748 \\
(3.86)^{* *}\end{array}$ & $\begin{array}{l}206.628 \\
(8.25)^{* *}\end{array}$ \\
\hline $\begin{array}{l}\text { Log total annual per capita } \\
\text { household expenditure (log EXP) }\end{array}$ & $\begin{array}{l}-0.115 \\
(- \\
19.93)^{* *}\end{array}$ & $\begin{array}{l}0.049 \\
(12.54) * *\end{array}$ & $\begin{array}{l}0.011 \\
(2.66) * *\end{array}$ & $\begin{array}{l}-0.001 \\
(-0.41)\end{array}$ & $\begin{array}{l}0.016 \\
(8.45)^{* *}\end{array}$ & $\begin{array}{l}0.041 \\
(10.73)^{* *}\end{array}$ \\
\hline $\begin{array}{l}\text { Internal remittances dummy } \\
\text { (INTREM) }\end{array}$ & $\begin{array}{l}0.004 \\
(0.11) \\
\end{array}$ & $\begin{array}{l}0.058 \\
(2.04)^{*}\end{array}$ & $\begin{array}{l}-0.080 \\
(-2.74)^{* *}\end{array}$ & $\begin{array}{l}-0.008 \\
(-0.48)\end{array}$ & $\begin{array}{l}-0.012 \\
(-0.93) \\
\end{array}$ & $\begin{array}{l}0.038 \\
(1.35) \\
\end{array}$ \\
\hline $\begin{array}{l}\text { (Internal remittances dummy) x } \\
\text { (Total household expenditure) } \\
(\text { INTREM })(\log \text { EXP) }\end{array}$ & $\begin{array}{l}-0.001 \\
(-0.32)\end{array}$ & $\begin{array}{l}-0.007 \\
(-2.17)^{*}\end{array}$ & $\begin{array}{l}0.010 \\
(3.13) * *\end{array}$ & $\begin{array}{l}0.001 \\
(0.78)\end{array}$ & $\begin{array}{l}0.001 \\
(1.04)\end{array}$ & $\begin{array}{l}-0.004 \\
(-1.54)^{*}\end{array}$ \\
\hline $\begin{array}{l}\text { International remittances dummy } \\
\text { (EXTREM) }\end{array}$ & $\begin{array}{l}-0.131 \\
(-2.17)^{*}\end{array}$ & $\begin{array}{l}0.007 \\
(0.18)\end{array}$ & $\begin{array}{l}0.051 \\
(1.24)\end{array}$ & $\begin{array}{l}-0.013 \\
(-0.53) \\
\end{array}$ & $\begin{array}{l}0.008 \\
(0.42)\end{array}$ & $\begin{array}{l}0.077 \\
(1.94)\end{array}$ \\
\hline $\begin{array}{l}\text { (International remittances dummy) x } \\
\text { (Total household expenditure) } \\
\text { (EXTREM)(log EXP) }\end{array}$ & $\begin{array}{l}0.012 \\
(1.88)\end{array}$ & $\begin{array}{l}0.001 \\
(0.09)\end{array}$ & $\begin{array}{l}-0.005 \\
(-1.20)\end{array}$ & $\begin{array}{l}0.002 \\
(0.89)\end{array}$ & $\begin{array}{l}-0.001 \\
(-0.59)\end{array}$ & $\begin{array}{l}-0.008 \\
(-1.96)^{*}\end{array}$ \\
\hline Household size (HS) & $\begin{array}{r}0.001 \\
(0.23)\end{array}$ & $\begin{array}{l}0.006 \\
(6.91)^{* *}\end{array}$ & $\begin{array}{l}-0.014 \\
(- \\
14.74) * *\end{array}$ & $\begin{array}{l}0.011 \\
(19.61)^{* *}\end{array}$ & $\begin{array}{l}-0.001 \\
(-1.96) *\end{array}$ & $\begin{array}{l}-0.002 \\
(-3.05) * *\end{array}$ \\
\hline Household size/total expenditure & $\begin{array}{l}16.114 \\
(4.32)^{* *}\end{array}$ & $\begin{array}{l}-3.482 \\
(-1.39)\end{array}$ & $\begin{array}{l}10.264 \\
(4.01)^{* *}\end{array}$ & $\begin{array}{l}-14.588 \\
(-9.74)^{* *}\end{array}$ & $\begin{array}{l}-0.082 \\
(-0.07)\end{array}$ & $\begin{array}{l}-8.226 \\
(-3.35) * *\end{array}$ \\
\hline Age of household head (AGEHD) & $\begin{array}{l}-0.001 \\
(-0.71)\end{array}$ & $\begin{array}{l}-0.001 \\
(-13.05)^{* *}\end{array}$ & $\begin{array}{l}0.001 \\
(14.62)^{* *}\end{array}$ & $\begin{array}{l}-0.001 \\
(-8.49) * *\end{array}$ & $\begin{array}{c}0.001 \\
(3.35)^{* *}\end{array}$ & $\begin{array}{l}0.001 \\
(2.72)^{* *}\end{array}$ \\
\hline $\begin{array}{l}\text { Age household head/total } \\
\text { expenditure }\end{array}$ & $\begin{array}{l}0.524 \\
(1.03)\end{array}$ & $\begin{array}{l}1.985 \\
(5.80) * *\end{array}$ & $\begin{array}{l}-2.895 \\
(-8.30)^{* *}\end{array}$ & $\begin{array}{l}0.673 \\
(3.31)^{* *}\end{array}$ & $\begin{array}{l}-0.032 \\
(-0.19)\end{array}$ & $\begin{array}{l}-0.256 \\
(-0.77)\end{array}$ \\
\hline $\begin{array}{l}\text { Number of children in household } \\
\text { less than } 5 \text { years (CHILD5) }\end{array}$ & $\begin{array}{l}-0.001 \\
(-0.17)\end{array}$ & $\begin{array}{c}0.005 \\
(2.38)^{*}\end{array}$ & $\begin{array}{l}0.010 \\
(4.35)^{* *}\end{array}$ & $\begin{array}{l}-0.029 \\
(-21.79) * *\end{array}$ & $\begin{array}{l}0.008 \\
(7.93)^{* *}\end{array}$ & $\begin{array}{l}0.006 \\
(2.65)^{* *}\end{array}$ \\
\hline Number children/total expenditure & $\begin{array}{l}2.285 \\
(0.25)\end{array}$ & $\begin{array}{l}-12.703 \\
(-2.06)^{*}\end{array}$ & $\begin{array}{l}-12.005 \\
(-1.91)\end{array}$ & $\begin{array}{l}45.550 \\
(12.38)^{* *}\end{array}$ & $\begin{array}{l}-13.817 \\
(- \\
4.63) * *\end{array}$ & $\begin{array}{l}-9.309 \\
(-1.54)\end{array}$ \\
\hline $\begin{array}{l}\text { Number household members } \\
\text { with preparatory education } \\
\text { (EDPREP) }\end{array}$ & $\begin{array}{l}-0.016 \\
(-1.30)\end{array}$ & $\begin{array}{r}0.011 \\
(1.29)\end{array}$ & $\begin{array}{l}0.001 \\
(0.04)\end{array}$ & $\begin{array}{l}-0.003 \\
(-0.71)\end{array}$ & $\begin{array}{l}0.006 \\
(1.45)\end{array}$ & $\begin{array}{l}0.002 \\
(0.33)\end{array}$ \\
\hline $\begin{array}{l}\text { Number preparatory education/total } \\
\text { expenditure }\end{array}$ & $\begin{array}{l}23.597 \\
(0.67) \\
\end{array}$ & $\begin{array}{l}-32.767 \\
(-1.37) \\
\end{array}$ & $\begin{array}{l}23.207 \\
(0.95)\end{array}$ & $\begin{array}{l}0.294 \\
(0.02) \\
\end{array}$ & $\begin{array}{l}-10.119 \\
(-0.88) \\
\end{array}$ & $\begin{array}{l}-4.212 \\
(-0.18) \\
\end{array}$ \\
\hline $\begin{array}{l}\text { Number household members } \\
\text { with primary education (EDPRIM) }\end{array}$ & $\begin{array}{l}-0.006 \\
(-2.53)^{*}\end{array}$ & $\begin{array}{l}0.008 \\
(4.83)^{* *}\end{array}$ & $\begin{array}{r}-0.001 \\
(-0.39) \\
\end{array}$ & $\begin{array}{l}-0.005 \\
(-5.18)^{* *}\end{array}$ & $\begin{array}{l}0.002 \\
(2.54)^{*}\end{array}$ & $\begin{array}{l}0.002 \\
(1.20)\end{array}$ \\
\hline $\begin{array}{l}\text { Number primary education/total } \\
\text { expenditure }\end{array}$ & $\begin{array}{l}-7.732 \\
(-1.17) \\
\end{array}$ & $\begin{array}{l}-11.342 \\
(-2.55)^{*}\end{array}$ & $\begin{array}{l}9.265 \\
(2.04)^{*}\end{array}$ & $\begin{array}{l}7.864 \\
(2.97) * *\end{array}$ & $\begin{array}{l}-0.582 \\
(-0.27) \\
\end{array}$ & $\begin{array}{l}2.528 \\
(0.58)\end{array}$ \\
\hline $\begin{array}{l}\text { Number household members } \\
\text { with secondary education (EDSEC) }\end{array}$ & $\begin{array}{l}-0.024 \\
(-8.10)^{* *}\end{array}$ & $\begin{array}{l}0.007 \\
(3.88)^{* *}\end{array}$ & $\begin{array}{l}0.001 \\
(0.02)\end{array}$ & $\begin{array}{l}0.011 \\
(9.26)^{* *}\end{array}$ & $\begin{array}{l}0.003 \\
(3.97)^{* *}\end{array}$ & $\begin{array}{l}0.001 \\
(0.70)\end{array}$ \\
\hline $\begin{array}{l}\text { Number secondary education/total } \\
\text { expenditure }\end{array}$ & $\begin{array}{l}-46.957 \\
(-3.29) * *\end{array}$ & $\begin{array}{l}-15.612 \\
(-1.62)\end{array}$ & $\begin{array}{l}19.540 \\
(1.99)^{*}\end{array}$ & $\begin{array}{l}36.102 \\
(6.30)^{* *}\end{array}$ & $\begin{array}{l}-3.625 \\
(-0.78)\end{array}$ & $\begin{array}{l}10.552 \\
(1.12)\end{array}$ \\
\hline $\begin{array}{l}\text { Number household members } \\
\text { with university education (EDUNIV) }\end{array}$ & $\begin{array}{l}-0.035 \\
(-6.82)^{* *}\end{array}$ & $\begin{array}{l}0.007 \\
(2.21)^{*}\end{array}$ & $\begin{array}{l}-0.001 \\
(-0.49)\end{array}$ & $\begin{array}{l}0.018 \\
(8.58)^{* *}\end{array}$ & $\begin{array}{l}0.006 \\
(3.50)^{* *}\end{array}$ & $\begin{array}{l}0.005 \\
(1.64)\end{array}$ \\
\hline $\begin{array}{l}\text { Number university education/total } \\
\text { expenditure }\end{array}$ & $\begin{array}{l}-34.324 \\
(-0.78)\end{array}$ & $\begin{array}{l}-41.397 \\
(-1.40)\end{array}$ & $\begin{array}{l}53.874 \\
(1.78)\end{array}$ & $\begin{array}{l}-8.666 \\
(-0.49)\end{array}$ & $\begin{array}{l}0.865 \\
(0.06)\end{array}$ & $\begin{array}{l}29.648 \\
(1.02) \\
\end{array}$ \\
\hline Constant & $\begin{array}{l}1.481 \\
(25.13) * *\end{array}$ & $\begin{array}{l}-0.266 \\
(-6.71) * *\end{array}$ & $\begin{array}{c}0.086 \\
(2.14)^{*}\end{array}$ & $\begin{array}{c}0.046 \\
(1.97)^{*}\end{array}$ & $\begin{array}{l}-0.129 \\
(- \\
6.74) * *\end{array}$ & $\begin{array}{l}-0.218 \\
(-5.63)^{* *}\end{array}$ \\
\hline Adj. $R^{2}$ & 0.412 & 0.155 & 0.202 & 0.331 & 0.092 & 0.080 \\
\hline F-statistic & 183.3 & 48.9 & 67.0 & 129.4 & 27.3 & 23.8 \\
\hline
\end{tabular}

Notes: $N=7,276$ households. Numbers in parentheses are t-statistics (two-tailed). One area dummy variable and seven regional variables are included in the equation, but are not reported in the table. All expenditure categories defined in Table 2. *Significant at the 0.05 level. $\quad * *$ Significant at the 0.01 level. 
Table 6. Marginal Budget Shares on Expenditure for Non-Remittance and Remittance-Receiving Households, Guatemala, 2000

\begin{tabular}{|l|l|l|l|c|c|}
\hline $\begin{array}{l}\text { Expenditure } \\
\text { Category }\end{array}$ & $\begin{array}{l}\text { Households } \\
\text { receiving } \\
\text { no } \\
\text { remittances } \\
\mathbf{( N = 5 6 6 5 )}\end{array}$ & $\begin{array}{l}\text { Households } \\
\text { receiving } \\
\text { internal } \\
\text { remittances } \\
\text { (from } \\
\text { Guatemala) } \\
\text { (N=1063) }\end{array}$ & $\begin{array}{l}\text { Households } \\
\text { receiving } \\
\text { international } \\
\text { remittances } \\
\text { from USA) } \\
\text { (N=593) }\end{array}$ & $\begin{array}{c}\text { Percentage } \\
\text { Change } \\
\text { (No } \\
\text { Remittances } \\
\text { vs. Internal } \\
\text { Remittances) }\end{array}$ & $\begin{array}{c}\text { Percentage } \\
\text { Change } \\
\text { (No } \\
\text { Remittances } \\
\text { vs. } \\
\text { International } \\
\text { Remittances) }\end{array}$ \\
\hline Food & 0.386 & 0.340 & 0.330 & $(-11.92)$ & $(-14.77)$ \\
\hline $\begin{array}{l}\text { Consumer } \\
\text { goods, } \\
\text { Durables }\end{array}$ & 0.203 & 0.202 & 0.229 & $(-0.50)$ & +12.81 \\
\hline Housing & 0.183 & 0.211 & 0.187 & & \\
\hline Education & 0.031 & 0.045 & 0.049 & +15.30 & +2.18 \\
\hline Health & 0.023 & 0.028 & 0.023 & +21.74 & +58.06 \\
\hline Other & 0.173 & 0.188 & 0.177 & +8.67 & +2.31 \\
\hline & 1.000 & 1.000 & 1.000 & & \\
\hline
\end{tabular}

Notes: Some figures do not sum to unity because of rounding. All expenditure categories defined in Table 2. 
Table 7: Expenditure Behavior on Housing for Non-Remittance and Remittance-Receiving Households Ranked by Quintile Group, Guatemala

\begin{tabular}{|c|c|c|c|c|c|}
\hline $\begin{array}{l}\text { Ranked by total } \\
\text { annual per capita } \\
\text { household } \\
\text { expenditure } \\
\text { (including } \\
\text { remittances) }\end{array}$ & $\begin{array}{l}\text { Percent of } \\
\text { households in } \\
\text { each group }\end{array}$ & $\begin{array}{l}\text { Mean of total } \\
\text { annual per capita } \\
\text { household } \\
\text { expenditure } \\
\text { (quetzals) }\end{array}$ & $\begin{array}{l}\text { Mean of per } \\
\text { capita household } \\
\text { expenditure on } \\
\text { Housing } \\
\text { (quetzals) }\end{array}$ & $\begin{array}{l}\text { Expenditure } \\
\text { elasticity }\end{array}$ & $\begin{array}{l}\text { Marginal } \\
\text { budget share } \\
\text { to Housing }\end{array}$ \\
\hline \multicolumn{6}{|l|}{$\begin{array}{l}\text { Households } \\
\text { receiving no } \\
\text { remittances } \\
(\mathrm{N}=5665)\end{array}$} \\
\hline Lowest $20 \%$ & 22.36 & 1789.55 & 193.39 & 1.435 & 0.155 \\
\hline Second $20 \%$ & 20.91 & 3136.13 & 336.08 & 1.654 & 0.177 \\
\hline Third 20\% & 20.08 & 4726.86 & 559.02 & 1.161 & 0.137 \\
\hline Fourth $20 \%$ & 18.56 & 7170.45 & 1031.94 & 0.472 & 0.068 \\
\hline Top 20\% & $\underline{18.09}$ & 21906.99 & $\underline{3902.02}$ & $\underline{0.550}$ & $\underline{0.098}$ \\
\hline All & 100.00 & 7399.32 & 1123.23 & 1.204 & 0.183 \\
\hline \multicolumn{6}{|l|}{$\begin{array}{l}\text { Households } \\
\text { receiving internal } \\
\text { remittances (from } \\
\text { Guatemala) } \\
(\mathrm{N}=1063)\end{array}$} \\
\hline Lowest $20 \%$ & 12.58 & 1919.11 & 208.19 & 1.373 & 0.149 \\
\hline Second $20 \%$ & 17.59 & 3171.74 & 376.88 & 1.936 & 0.230 \\
\hline Third 20\% & 19.35 & 4813.72 & 688.29 & 1.553 & 0.222 \\
\hline Fourth $20 \%$ & 25.39 & 7924.94 & 1213.31 & 0.457 & 0.070 \\
\hline Top 20\% & $\underline{25.09}$ & $\underline{19821.48}$ & $\underline{4536.65}$ & $\underline{0.917}$ & $\underline{0.210}$ \\
\hline All & 100.00 & 8715.82 & $\overline{1671.94}$ & $\overline{1.099}$ & $\overline{0.211}$ \\
\hline \multicolumn{6}{|l|}{$\begin{array}{l}\text { Households } \\
\text { receiving } \\
\text { international } \\
\text { remittances (from } \\
\text { USA) }(\mathrm{N}=593)\end{array}$} \\
\hline Lowest $20 \%$ & 7.80 & 2028.49 & 237.91 & 1.816 & 0.213 \\
\hline Second $20 \%$ & 15.48 & 3218.77 & 374.05 & 1.901 & 0.221 \\
\hline Third 20\% & 19.98 & 4792.90 & 558.40 & 1.802 & 0.210 \\
\hline Fourth $20 \%$ & 27.08 & 7696.89 & 1041.56 & 0.547 & 0.074 \\
\hline Top 20\% & $\underline{29.66}$ & $\underline{18961.74}$ & $\underline{3678.76}$ & $\underline{0.701}$ & $\underline{0.136}$ \\
\hline All & 100.00 & 9323.21 & 1561.33 & 1.117 & 0.187 \\
\hline
\end{tabular}

Note: In 2000, 1 Guatemala quetzal $=$ US\$ 0.128 
Table 8: Expenditure Behavior on Education for Non-Remittance and Remittance-Receiving Households Ranked by Quintile Group, Guatemala

\begin{tabular}{|c|c|c|c|c|c|}
\hline $\begin{array}{l}\text { Ranked by total } \\
\text { annual per capita } \\
\text { household } \\
\text { expenditure } \\
\text { (including } \\
\text { remittances) }\end{array}$ & $\begin{array}{l}\text { Percent of } \\
\text { households in } \\
\text { each group }\end{array}$ & $\begin{array}{l}\text { Mean of total } \\
\text { annual per capita } \\
\text { household } \\
\text { expenditure } \\
\text { (quetzals) }\end{array}$ & $\begin{array}{l}\text { Mean of per } \\
\text { capita household } \\
\text { expenditure on } \\
\text { Education } \\
\text { (quetzals) }\end{array}$ & $\begin{array}{l}\text { Expenditure } \\
\text { elasticity }\end{array}$ & $\begin{array}{l}\text { Marginal } \\
\text { budget share to } \\
\text { Education }\end{array}$ \\
\hline \multicolumn{6}{|l|}{$\begin{array}{l}\text { Households } \\
\text { receiving no } \\
\text { remittances } \\
(\mathrm{N}=5665)\end{array}$} \\
\hline Lowest $20 \%$ & 22.36 & 1789.55 & 28.92 & 2.068 & 0.033 \\
\hline Second $20 \%$ & 20.91 & 3136.13 & 70.48 & 3.732 & 0.084 \\
\hline Third 20\% & 20.08 & 4726.86 & 136.85 & 0.574 & 0.017 \\
\hline Fourth $20 \%$ & 18.56 & 7710.54 & 295.71 & 0.269 & 0.011 \\
\hline Top 20\% & $\underline{18.07}$ & 21906.99 & 1158.96 & 0.672 & $\underline{0.036}$ \\
\hline All & 100.00 & 7399.32 & 313.26 & 0.730 & 0.031 \\
\hline \multicolumn{6}{|l|}{$\begin{array}{l}\text { Households } \\
\text { receiving internal } \\
\text { remittances (from } \\
\text { Guatemala) } \\
(\mathrm{N}=1063)\end{array}$} \\
\hline Lowest $20 \%$ & 12.58 & 1919.11 & 24.97 & 2.228 & 0.029 \\
\hline Second $20 \%$ & 17.59 & 3171.74 & 84.77 & 3.442 & 0.092 \\
\hline Third 20\% & 19.35 & 4813.72 & 133.57 & 1.874 & 0.052 \\
\hline Fourth $20 \%$ & 25.39 & 7924.94 & 360.17 & 0.946 & 0.043 \\
\hline Top 20\% & $\underline{25.09}$ & $\underline{19821.48}$ & $\underline{1099.75}$ & $\underline{0.216}$ & $\underline{0.012}$ \\
\hline All & 100.00 & 8715.82 & 411.14 & $\overline{0.954}$ & $\overline{0.045}$ \\
\hline \multicolumn{6}{|l|}{$\begin{array}{l}\text { Households } \\
\text { receiving } \\
\text { international } \\
\text { remittances (from } \\
\text { USA) }(\mathrm{N}=593)\end{array}$} \\
\hline Lowest $20 \%$ & 7.80 & 2028.49 & 57.10 & 2.309 & 0.065 \\
\hline Second $20 \%$ & 15.48 & 3218.77 & 102.57 & 1.600 & 0.051 \\
\hline Third 20\% & 19.98 & 4792.90 & 237.35 & 2.000 & 0.099 \\
\hline Fourth $20 \%$ & 27.08 & 7696.89 & 394.23 & 0.703 & 0.036 \\
\hline Top $20 \%$ & $\underline{29.66}$ & $\underline{18961.74}$ & $\underline{912.80}$ & $\underline{1.475}$ & $\underline{0.071}$ \\
\hline All & 100.0 & 9323.21 & 445.35 & 1.026 & 0.049 \\
\hline
\end{tabular}

Note: In 2000, 1 Guatemala quetzal = US\$ 0.128 
Table 9. OLS Regression Analysis of Household Expenditure on Education, Without Remittance Variables

\begin{tabular}{|c|c|c|c|c|}
\hline Variable & $\begin{array}{l}\text { Preparatory } \\
\text { education }^{1}\end{array}$ & $\begin{array}{l}\text { Primary } \\
\text { education }^{1}\end{array}$ & $\begin{array}{l}\text { Secondary } \\
\text { education }\end{array}$ & $\begin{array}{l}\text { Higher/university } \\
\text { Education }^{1}\end{array}$ \\
\hline $\begin{array}{l}\text { Reciprocal of total per capita } \\
\text { expenditure }\left(\alpha_{i} / \text { EXP }\right)\end{array}$ & $\begin{array}{l}0.421 \\
(0.36)\end{array}$ & $\begin{array}{l}-0.391 \\
(-0.05)\end{array}$ & $\begin{array}{l}-9.891 \\
(-0.72)\end{array}$ & $\begin{array}{l}30.423 \\
(4.26)^{* *}\end{array}$ \\
\hline $\begin{array}{l}\text { Log total annual per capita } \\
\text { Household expenditure (log } \\
\text { EXP) }\end{array}$ & $\begin{array}{l}-0.001 \\
(-0.55)\end{array}$ & $\begin{array}{l}-0.001 \\
(-1.44)\end{array}$ & $\begin{array}{l}0.001 \\
(0.64)\end{array}$ & $\begin{array}{l}0.004 \\
(3.54)^{* *}\end{array}$ \\
\hline Household size (HS) & $\begin{array}{l}0.001 \\
(1.37)\end{array}$ & $\begin{array}{l}0.005 \\
(20.47) * *\end{array}$ & $\begin{array}{l}0.009 \\
(19.89) * *\end{array}$ & $\begin{array}{l}0.002 \\
(8.71)^{* *}\end{array}$ \\
\hline $\begin{array}{l}\text { Household size/total } \\
\text { expenditure }\end{array}$ & $\begin{array}{l}-0.074 \\
(-0.69)\end{array}$ & $\begin{array}{l}-4.647 \\
(-6.70)^{* *}\end{array}$ & $\begin{array}{l}-12.953 \\
(- \\
10.12)^{* *}\end{array}$ & $\begin{array}{l}-3.977 \\
(-6.01)^{* *}\end{array}$ \\
\hline $\begin{array}{l}\text { Age of household head } \\
\text { (AGEHD) }\end{array}$ & $\begin{array}{l}-0.001 \\
(-1.47)\end{array}$ & $\begin{array}{l}-0.001 \\
(-6.31) * *\end{array}$ & $\begin{array}{l}-0.001 \\
(-3.30)^{* *}\end{array}$ & $\begin{array}{l}0.001 \\
(2.41)^{*}\end{array}$ \\
\hline $\begin{array}{l}\text { Age of household head/total } \\
\text { expenditure }\end{array}$ & $\begin{array}{l}0.014 \\
(0.83)\end{array}$ & $\begin{array}{l}0.207 \\
(1.88)\end{array}$ & $\begin{array}{l}0.499 \\
(2.46)^{*}\end{array}$ & $\begin{array}{l}-0.099 \\
(-0.94)\end{array}$ \\
\hline $\begin{array}{l}\text { Number of children in } \\
\text { household } \\
\text { less than } 5 \text { years (CHILD5) }\end{array}$ & $\begin{array}{l}0.001 \\
(0.19)\end{array}$ & $\begin{array}{l}-0.009 \\
(13.92)^{* *}\end{array}$ & $\begin{array}{l}-0.023 \\
(- \\
18.35) * *\end{array}$ & $\begin{array}{l}-0.003 \\
(-5.55)^{* *}\end{array}$ \\
\hline $\begin{array}{l}\text { Number children/total } \\
\text { expenditure }\end{array}$ & $\begin{array}{l}0.020 \\
(0.07)\end{array}$ & $\begin{array}{l}10.608 \\
(5.65)^{* *}\end{array}$ & $\begin{array}{l}37.931 \\
(10.95)^{* *}\end{array}$ & $\begin{array}{l}7.954 \\
(4.44)^{* *}\end{array}$ \\
\hline $\begin{array}{l}\text { Years of education of } \\
\text { Household head (EDHD) }\end{array}$ & $\begin{array}{l}0.001 \\
(2.06) *\end{array}$ & $\begin{array}{l}0.001 \\
(3.82) * *\end{array}$ & $\begin{array}{l}0.001 \\
(2.99) * *\end{array}$ & $\begin{array}{l}0.001 \\
(9.69) * *\end{array}$ \\
\hline $\begin{array}{l}\text { Education household } \\
\text { head/total expenditure }\end{array}$ & $\begin{array}{l}-0.085 \\
(-0.98)\end{array}$ & $\begin{array}{l}-0.109 \\
(-0.20)\end{array}$ & $\begin{array}{l}0.990 \\
(0.96)\end{array}$ & $\begin{array}{l}-2.912 \\
(-5.44) * *\end{array}$ \\
\hline $\begin{array}{l}\text { Female head }(1=\text { female } \\
\text { head of household (FEMHD) }\end{array}$ & $\begin{array}{l}0.001 \\
(1.32)\end{array}$ & $\begin{array}{l}0.003 \\
(2.50)^{*}\end{array}$ & $\begin{array}{l}0.014 \\
(6.23) * *\end{array}$ & $\begin{array}{l}0.005 \\
(4.14) * *\end{array}$ \\
\hline Female head/total expenditure & $\begin{array}{l}-0.494 \\
(-0.77)\end{array}$ & $\begin{array}{l}6.224 \\
(1.49)\end{array}$ & $\begin{array}{l}-19.249 \\
(-2.51)^{*}\end{array}$ & $\begin{array}{l}-9.577 \\
(-2.41)^{*}\end{array}$ \\
\hline Constant & $\begin{array}{l}0.002 \\
(0.96)\end{array}$ & $\begin{array}{l}0.027 \\
(2.25)^{*}\end{array}$ & $\begin{array}{l}-0.006 \\
(-0.27)\end{array}$ & $\begin{array}{l}-0.050 \\
(-4.41)^{* *}\end{array}$ \\
\hline Adj. $R^{2}$ & 0.006 & 0.128 & 0.128 & 0.078 \\
\hline F-statistic & 3.33 & 54.32 & 54.28 & 31.79 \\
\hline
\end{tabular}

Notes: $\mathrm{N}=7,276$ households. Numbers in parenthesis are $\mathrm{t}$-statistics (two-tailed). One area dummy variable and seven regional variables are included in the equation, but are not reported in the table.

* Significant at the 0.05 level. $\quad * *$ Significant at the 0.01 level

${ }^{1}$ Preparatory education is $1-2$ years, primary is grades $1-6$, secondary is grades $7-12$, and higher/university is 4 years. 
Table 10. OLS Regression Analysis of Household Expenditure on Education, With Remittance Variables

\begin{tabular}{|c|c|c|c|c|}
\hline Variable & $\begin{array}{l}\text { Preparatory } \\
\text { education }^{1}\end{array}$ & $\begin{array}{l}\text { Primary } \\
\text { education }^{1}\end{array}$ & $\begin{array}{l}\text { Secondary } \\
\text { education }^{1}\end{array}$ & $\begin{array}{l}\text { Higher/university } \\
\text { education }^{1}\end{array}$ \\
\hline $\begin{array}{l}\text { Reciprocal of total per capita } \\
\text { expenditure }\left(\alpha_{i} / E X P\right)\end{array}$ & $\begin{array}{l}0.598 \\
(0.51)\end{array}$ & $\begin{array}{l}1.226 \\
(0.16)\end{array}$ & $\begin{array}{l}-12.953 \\
(-0.93)\end{array}$ & $\begin{array}{l}28.623 \\
(3.97) * *\end{array}$ \\
\hline $\begin{array}{l}\text { Log total annual per capita } \\
\text { Household expenditure (log EXP) }\end{array}$ & $\begin{array}{l}-0.001 \\
(-0.29)\end{array}$ & $\begin{array}{l}-0.001 \\
(-1.10)\end{array}$ & $\begin{array}{l}0.001 \\
(0.07)\end{array}$ & $\begin{array}{l}0.004 \\
(3.19) * *\end{array}$ \\
\hline $\begin{array}{l}\text { Internal remittances dummy } \\
\text { (INTREM) }\end{array}$ & $\begin{array}{l}0.001 \\
(0.050)\end{array}$ & $\begin{array}{l}0.007 \\
(0.86)\end{array}$ & $\begin{array}{l}0.002 \\
(0.18)\end{array}$ & $\begin{array}{l}-0.017 \\
(-2.01)^{*}\end{array}$ \\
\hline $\begin{array}{l}\text { (Internal remittances dummy) x } \\
\text { (Total household expenditure) } \\
\text { (INTREM)(log EXP) }\end{array}$ & $\begin{array}{l}-0.001 \\
(-0.47)\end{array}$ & $\begin{array}{l}-0.001 \\
(-0.84)\end{array}$ & $\begin{array}{l}-0.001 \\
(-0.06)\end{array}$ & $\begin{array}{l}0.002 \\
(2.18)^{*}\end{array}$ \\
\hline $\begin{array}{l}\text { International remittances dummy } \\
\text { (EXTREM) }\end{array}$ & $\begin{array}{l}0.002 \\
(1.34)\end{array}$ & $\begin{array}{l}0.023 \\
(1.83)\end{array}$ & $\begin{array}{l}-0.055 \\
(-2.38)^{*}\end{array}$ & $\begin{array}{l}-0.008 \\
(-0.68)\end{array}$ \\
\hline $\begin{array}{l}\text { (International remittances dummy) x } \\
\text { (Total household expenditure) } \\
\text { (EXTREM)(log EXP) }\end{array}$ & $\begin{array}{l}-0.001 \\
(-1.32)\end{array}$ & $\begin{array}{l}-0.002 \\
(-1.71)\end{array}$ & $\begin{array}{l}0.007 \\
(2.65)^{* *}\end{array}$ & $\begin{array}{l}0.001 \\
(0.51)\end{array}$ \\
\hline Household size (HS) & $\begin{array}{l}0.001 \\
(1.37)\end{array}$ & $\begin{array}{l}0.005 \\
(20.30)^{* *}\end{array}$ & $\begin{array}{l}0.009 \\
(19.55)^{* *}\end{array}$ & $\begin{array}{l}0.002 \\
(8.84) * *\end{array}$ \\
\hline Household size/total expenditure & $\begin{array}{l}-0.076 \\
(-0.71)\end{array}$ & $\begin{array}{l}-4.638 \\
(-6.68)^{* *}\end{array}$ & $\begin{array}{l}-12.706 \\
(-9.92)^{* *}\end{array}$ & $\begin{array}{l}-4.014 \\
(-6.07)^{* *}\end{array}$ \\
\hline Age of household head (AGEHD) & $\begin{array}{l}-0.001 \\
(-1.49)\end{array}$ & $\begin{array}{l}-0.001 \\
(-6.28)^{* *}\end{array}$ & $\begin{array}{l}-0.001 \\
(-3.46) * *\end{array}$ & $\begin{array}{l}0.001 \\
(2.13) *\end{array}$ \\
\hline $\begin{array}{l}\text { Age of household head/total } \\
\text { expenditure }\end{array}$ & $\begin{array}{l}0.013 \\
(0.79)\end{array}$ & $\begin{array}{l}0.198 \\
(1.80)\end{array}$ & $\begin{array}{l}0.507 \\
(2.49)^{*}\end{array}$ & $\begin{array}{l}-0.076 \\
(-0.73)\end{array}$ \\
\hline $\begin{array}{l}\text { Number of children in household } \\
\text { less than } 5 \text { years (CHILD5) }\end{array}$ & $\begin{array}{l}0.001 \\
(0.20)\end{array}$ & $\begin{array}{l}-0.009 \\
(- \\
13.88)^{* *}\end{array}$ & $\begin{array}{l}-0.023 \\
(- \\
18.33)^{* *}\end{array}$ & $\begin{array}{l}-0.003 \\
(-5.64)^{* *}\end{array}$ \\
\hline $\begin{array}{l}\text { Number children/total } \\
\text { expenditure }\end{array}$ & $\begin{array}{l}0.009 \\
(0.03) \\
\end{array}$ & $\begin{array}{l}10.465 \\
(5.57)^{* *}\end{array}$ & $\begin{array}{l}37.766 \\
(10.91)^{* *}\end{array}$ & $\begin{array}{l}8.113 \\
(4.53) * *\end{array}$ \\
\hline $\begin{array}{l}\text { Years of education of } \\
\text { household head (EDHD) }\end{array}$ & $\begin{array}{l}0.001 \\
(2.02)^{*}\end{array}$ & $\begin{array}{l}0.001 \\
(3.82)^{* *}\end{array}$ & $\begin{array}{l}0.001 \\
(3.24)^{* *}\end{array}$ & $\begin{array}{l}0.001 \\
(9.60)^{* *}\end{array}$ \\
\hline $\begin{array}{l}\text { Education household head/total } \\
\text { expenditure }\end{array}$ & $\begin{array}{l}-0.082 \\
(-0.95)\end{array}$ & $\begin{array}{l}-0.102 \\
(-0.18)\end{array}$ & $\begin{array}{l}0.812 \\
(0.78)\end{array}$ & $\begin{array}{l}-2.887 \\
(-5.39) * *\end{array}$ \\
\hline $\begin{array}{l}\text { Female head }(1=\text { female } \\
\text { head of household (FEMHD) }\end{array}$ & $\begin{array}{l}0.001 \\
(1.35)\end{array}$ & $\begin{array}{l}0.003 \\
(2.48)^{*}\end{array}$ & $\begin{array}{l}0.012 \\
(5.54)^{* *}\end{array}$ & $\begin{array}{l}0.004 \\
(3.80)^{* *}\end{array}$ \\
\hline Female head/total expenditure & $\begin{array}{l}-0.604 \\
(-0.92)\end{array}$ & $\begin{array}{l}5.266 \\
(1.24)\end{array}$ & $\begin{array}{l}-17.313 \\
(-2.22)^{*}\end{array}$ & $\begin{array}{l}-8.276 \\
(-2.05)^{*}\end{array}$ \\
\hline Constant & $\begin{array}{l}0.001 \\
(0.70)\end{array}$ & $\begin{array}{l}0.023 \\
(1.91)\end{array}$ & $\begin{array}{l}0.006 \\
(0.27)\end{array}$ & $\begin{array}{l}-0.047 \\
(-4.04) * *\end{array}$ \\
\hline Adj. $R^{2}$ & 0.006 & 0.128 & 0.129 & 0.079 \\
\hline F-statistic & 2.86 & 45.51 & 46.08 & 27.06 \\
\hline
\end{tabular}

Notes: $\mathrm{N}=7,276$ households. Numbers in parenthesis are t-statistic (two-tailed). One area dummy variable and seven regional variables are included in the equation, but are not reported in the table.

* Significant at the 0.05 level. $\quad * *$ Significant at the 0.01 level

\footnotetext{
${ }^{1}$ Preparatory education is $1-2$ years, primary is grades $1-6$, secondary is grades $7-12$, and higher/university is 4 years.
} 
Table 11. Marginal Budget Shares on Education for Non-Remittance and RemittanceReceiving Households, Guatemala

\begin{tabular}{|l|l|l|l|c|c|}
\hline $\begin{array}{l}\text { Eevel of } \\
\text { Education }\end{array}$ & $\begin{array}{l}\text { Households } \\
\text { receiving } \\
\text { no } \\
\text { remittances } \\
(\mathrm{N}=5665)\end{array}$ & $\begin{array}{l}\text { Households } \\
\text { receiving } \\
\text { internal } \\
\text { remittances } \\
\text { from } \\
\text { Guatemala) } \\
(\mathrm{N}=1063)\end{array}$ & $\begin{array}{l}\text { Households } \\
\text { receiving } \\
\text { international } \\
\text { remittances } \\
\text { from USA) } \\
(\mathrm{N}=593)\end{array}$ & $\begin{array}{c}\text { Percentage } \\
\text { Change } \\
\text { (No } \\
\text { Remittances } \\
\text { vs. Internal } \\
\text { Remittances }\end{array}$ & $\begin{array}{c}\text { Percentage } \\
\text { Change } \\
\text { No } \\
\text { Remittances } \\
\text { vs. } \\
\text { International } \\
\text { Remittances })\end{array}$ \\
\hline Preparatory & 0.00082 & 0.00074 & 0.00099 & $(-9.80)$ & +12.19 \\
\hline Primary & 0.00985 & 0.01061 & 0.00991 & +7.71 & +0.61 \\
\hline Secondary & 0.00800 & 0.00957 & 0.01939 & +19.62 & +142.37 \\
\hline Higher/University & 0.01025 & 0.00589 & 0.01050 & $(-57.46)$ & +2.44 \\
\hline
\end{tabular}

\footnotetext{
${ }^{1}$ Preparatory education is 1-2 years, primary is grades $1-6$, secondary is grades $7-12$, and university is 4 years.
} 


\begin{abstract}
Notes
${ }^{\mathrm{i}}$ These figures for official international remittances do not include the large - and unknown - amount of international remittances which return to developing countries through unrecorded, informal channels.

${ }^{\text {ii }}$ Adams (1991) found that in rural Egypt international remittances increase the marginal propensity to invest in land and housing. Alderman (1996) found that international remittances in rural Pakistan tend to go into housing, and Adams (1998) found that remittances monies were invested in two kinds of physical assets: irrigated and rainfed land.

iii This 2000 Guatemala household survey was implemented as part of the "Program for the Improvement of Surveys and Measurement of Living Conditions in Latin America and the Caribbean" (ENCOVI), which was sponsored by the Inter-American Development Bank (IDB), the World Bank and the Economic Committee for Latin America and the Caribbean (CEPAL).

${ }^{\text {iv }}$ For more details on this 2000 Guatemala ENCOVI household survey, see World Bank (2004).

"The five possible responses to this "where do these people sending (your household) remittances live" question were: (1) Guatemala; (2) United States; (3) Mexico; (4) Central America; and (5) other countries.

${ }^{\mathrm{vi}}$ The functional form used in this analysis differs from the Working-Leser model because it includes an intercept in equation (3). In theory, $\mathrm{C}_{i}$ should always equal zero whenever total expenditure EXP is zero, and this restriction should be built into the function. But zero observations on EXP invariably lie well outside the sample range. Also, observing this restriction with the Working-Leser model can lead to poorer statistical fits. Including the intercept term in the model has little effect on the estimation of marginal budget shares for the average person, but it can make a significant difference for income redistribution results.

${ }^{\text {vii }}$ See, for example, Osili (2004), Adams (1991) and Gilani, Khan and Iqbal (1981).

${ }^{\text {viii }}$ While mean annual per capita expenditures for households receiving no remittances is 7399.3 quetzals/capita/year, it rises to 8,715.8 quetzals/capita/year for households receiving internal remittances (from Guatemala) and to 9,323.2 quetzals/capita/year for households receiving international remittances (from USA).

${ }^{\text {ix }}$ Unfortunately, few studies have tried to measure the second- and third-round multiplier effects of remittance expenditures on housing on wages, employment and development in the local economy. One possible exception to this statement is Taylor and Adelman (1996).

${ }^{\mathrm{x}}$ In Table 11 it is not clear why households receiving internal remittances are spending less at the margin on higher/university education than households which do not receive remittances.

${ }^{x i}$ These marginal budget shares for consumption goods are reported in Table 6.
\end{abstract}

